\title{
Ataraxía e investigação em Sexto Empírico
}

\author{
Luiz Antonio Alves Eva \\ Universidade Federal do $A B C$ (UFABC)
}

\section{RESUMO}

Neste artigo examino a noção de ataraxía tal como presente no ceticismo pirrônico de Sexto Empírico. Meu propósito é mostrar que, a despeito de conservar aspectos que parecem estar a ela associados desde a filosofia de Pirro, o sentido da noção de ataraxía muda substancialmente e passa a possuir, ao menos nas Hipotiposes, um aspecto fundamental de ordem "intelectual" associado à supressão de um tipo específico de perturbação filosófica. Pretendo igualmente mostrar que tal peculiaridade permitiria compreender como ele se relacionaria de modo coerente com a noção de investigação cética pirrônica e, para tanto, como ele se associa com a noção de "terapia filosófica” e de "epokhé sobre todas as coisas" que se fazem presentes na obra de Sexto.

\section{PALAVRAS-CHAVE}

Ceticismo;

Sexto Empírico;

Pirronismo.

\section{ABSTRACT}

In this paper I examine the notion of ataraxia as present in the pyrrhonian skepticism of Sextus Empiricus. My purpose is to show that, in spite of preserving aspects that seem to be associated with this concept already in Pyrrho's philosophy, it changes substantially and has, at least in the Hypotypes, a fundamental aspect corresponding to an "intellectual" tranquility associated with the suppression of the type of philosophical disturbance that skepticism would remove. I would also like to show that such a peculiarity would allow us to understand how it would relate in a coherent way to the notion of Pyrrhonic skeptical inquiry. In order to achieve it, we also examinate how it is connected with Sextus's conceptions of "philosophical therapy" and "epokhe about all things".

\section{KEY WORDS}

Skepticism;

Sixth Empirical;

Pyrronism. 
... Nunca pude aceitar sua proposta filosófica de uma investigação continuada. Por que prosseguir na busca, quando nenhuma esperança se justifica e nada mais se tem que a experiência repetida do fracasso? A ataraxía cética, eu fui incapaz de atingi-la...

Porchat, "Prefácio a uma Filosofia"

Nas Hipotiposes Pirrônicas, Sexto Empírico informa que o fim (télos) da filosofia cética é a "liberdade da perturbação (ou tranquilidade da alma, ataraxía) nas coisas que dependem de opinião e a moderação nas afecçôes necessárias (metriopátheia)" 2 (Sexto Empírico, 1994, 25-30). Enquanto o tema da metriopátheia se fez presente já na filosofia de Aristóteles, a ataraxía aparece principalmente nas demais filosofias helenísticas; também os estoicos e os epicuristas lhe conferiram papel central, associando-a à sabedoria. Segundo Flintoff, talvez tenha sido Pirro o responsável pela introdução desse termo na filosofia grega, pois a ataraxía é um termo ausente do vocabulário filosófico e poético tradicional anterior a ele, tratando-se possivelmente de um termo proveniente do contexto militar (Flintoff, I980, p. 95-96) ${ }^{3}$. Ao menos, esse é o contexto da célebre passagem -- proveniente de Posidônio, segundo Diógenes Laércio -- segundo a qual Pirro, para recobrar o moral da tripulação aflita de um barco em meio à tempestade, apontou a indiferença de um porco que comia no convés como um exemplo a ser seguido pelo sábio (DL, IX, p. 68) ${ }^{4}$.

Outra informação relevante sobre a origem dessa temática é também dada por Diógenes: a filosofia de Pirro teria sido, diz ele, inspirada pelo contato que esse filósofo teve com os magi e gimnosofistas (os "sábios nus") em sua incursão pela Ásia Menor e pela Índia na expedição de Alexandre (DL, IX, p. 6I). Flintoff sustenta que esse testemunho seria autêntico, mas ressalta que náo se deve esperar encontrar, na influência das sabedorias orientais, uma fonte da noção de ataraxía propriamente dita. A semelhança entre esse ideal filosófico e outros conceitos próprios do budismo, segundo ele, se mostraria principalmente no modo como ele se formula em

1 Este texto é uma versão substancialmente modificada do que foi apresentado no colóquio "Ceticismo, Filosofia e História da Filosofia: Homenagem a Oswaldo Porchat”, em I4 de agosto de 20I8. Gostaria de agradecer a todos os ouvintes que, nessa ocasião, o discutiram. Diversas das sugestóes dadas na ocasiáo foram aqui incorporadas.

2 Doravante nos referiremos a essa obra como HP. Em HP I, I2, o próprio Sexto esclarece que "ataraxía” pode ser entendido como "liberdade da perturbaçáo ou tranquilidade da alma".

3 Segundo este comentador, Demócrito talves tenha sido o primeiro filósofo a introduzir uma finalidade moral específica como meta da sabedoria, tendo proposto o como fim a euthimía (serenidade), da qual um dos aspectos seria a athambia (imperturbilidade) (Ibid.).

4 Diógenes Laércio, Vidas dos Filósofos Ilustres, IX, "Vida de Pirro". Citado a partir da tradução de Gabriela Gazzinelli em Gazzinelli, 20I3. 
termos meramente negativos, como uma remoção da perturbação, ou imperturbabilidade (Fintoff, 1980, p. 94). De todo modo, a ataraxía pode ter se integrado, no seu modo de vida filosófico próprio, a outros aspectos herdados das filosofias orientais, manifestos em sua busca da superação da experiência da dor, de recolhimento e recusa de engajamento em nos afazeres públicos (apragmosyne), e talvez na opçáo por uma vida errante (Ibid., p. 97-IOo).

O tema da ataraxía é central naquele que é tido como o testemunho mais antigo que dispomos sobre a filosofia própria de Pirro (que nada escreveu), proveniente de seu discípulo Timão. Sendo as coisas "igualmente indiferentes, instáveis e indecidíveis", diz o texto, segue-se que não se deve crer nelas, mas permanecer "sem opiniōes, inclinaçóes e hesitaçóes”, e “[...] para os assim dispostos, Timáo diz que há de surgir primeiro a afasia e, em seguida, a tranquilidade e, de acordo com Enesidemo, o prazer" 5 (Eusébio, Preparação Evangélica, I4.8.4.). Essa passagem indica a existência de alguma relação direta entre, de uma parte, a não-opinião e a afasia (elementos talvez afinados às filosofias orientais, mas também precursores da noçáo cética de suspensão do juízo [Flintoff, I980, p. 9I]) e, de outra, o estado de imperturbabilidade que daí se seguiria. Diversamente do modo como, mais comumente na filosofia grega, a formulação de aporias teria um propósito erístico (como em Sócrates ou nos sofistas), para Pirro a aporia teria assim sido vista como boa ou desejável por si, em vista de seu poder de conduzir à imperturbabilidade.

Mas o que restaria dessa concepção original de ataraxía no ceticismo de Sexto Empírico, que será formulado cerca de cinco séculos mais tarde? Estudos têm salientado diferenças importantes entre o que seria o pirronismo original e sua reconstrução tardia, a começar pelo fato de que Pirro, ao sustentar que as coisas são "igualmente indiferentes, instáveis e indecidíveis", parece ter endossado uma posição que, sob a ótica do ceticismo de Sexto, estaria mais próxima de um dogmatismo do que do ceticismo propriamente dito (ver, p. ex., Sedley, I983 e Bett, 2000). Os céticos, tal como Sexto os apresenta, não teriam pretendido se posicionar sobre esse tema; em vez disso, eles suspenderam seu juízo sobre o que as coisas são em si mesmas. Eles se apresentaram como "aqueles que investigam" (skeptikói), isto é, os que permaneceram investigando por não terem ainda encontrado a verdade, por oposição aos dogmáticos (que pensam ter encontrado a verdade) e aos filósofos da Nova Academia (que, segundo ele, julgariam a verdade inapreensível [HP I, I-4]). Assim, a própria maneira como esses filósofos se autodenominaram evidencia o papel central

\footnotetext{
5 Eusébio atribui o testemunho a Aristocles de Messina, que o teria compilado diretamente de uma passagem de Timão, discípulo direto de Pirro.
} 
que conferiram à noção de investigação (sképsis ou zétesis), ainda que, um tanto paradoxalmente (em vista de como Sexto se refere à filosofia acadêmica), esse talvez seja um dentre outros elementos que o pirronismo tardio herdou da filosofia da Nova Academia. ${ }^{6}$

Esta outra filosofia de cunho cético foi primeiramente formulada por Arcesilau, líder da Academia que pretendeu retomar radicalmente o socratismo, e posteriormente desenvolvida por outros de seus sucessores, como Carnéades e Clitômaco. Posteriormente, o acadêmico Enesidemo, no século I a.C., teria abandonado as fileiras dessa escola por julgar que ela tendia demasiado ao dogmatismo; a ele se atribui a revivescência tardia do pirronismo que, segundo Cícero, seria a essa altura uma filosofia inteiramente abandonada. Sexto Empírico, por sua vez, reconhece que o seu próprio ceticismo tem bastante afinidade com o de Arcesilau, ${ }^{7}$ mas identifica a sua filosofia da investigação com o pirronismo por julgar que "[...] Pirro parece ter se vinculado ao ceticismo mais sistematicamente e conspicuamente do que todos que o precederam...” (HP I, 7). Assim, embora Sexto também se diga pirrônico, isso parece se dever ao fato de que este filósofo antigo teria eventualmente também praticado essa mesma atividade investigativa, de busca da verdade - que constituiria, assim, o aspecto central de seu próprio modo de filosofar.

Seja como for, também para o pirrônico Sexto o fim do filosofia cética é a obtenção da ataraxía, algo que se segue da suspensão do juízo (epokhé) — noção associada à abstenção da dóxa, também presente no fragmento de Timão, mas que se admite ter sido explicitamente introduzida pelo acadêmico Arcesilau (Cícero, Academica, I, 45). Explicando o que é a investigação cética (sképsis), Sexto escreve: "O ceticismo é uma capacidade de realizar oposições entre coisas que aparecem [aos sentidos] e coisas pensadas, de todas as maneiras, uma capacidade pela qual, graças à equipolência dos objetos e discursos, nós [céticos] primeiro chegamos à suspensão do juízo e depois à tranquilidade da alma...” (HP I, 8).

\footnotetext{
6 Sexto enfatiza as divergências entre o ceticismo e a filosofia acadêmica referindo-se principalmente a Carnéades e Clitômaco. Veja-se, sobre o tema, Sedley, 1983, p. II-I3, 20-22., e Bolzani Filho, 20I3. O tema das relaçóes entre pirronismo e ceticismo acadêmico é proverbialmente controvertido. Sobre ele Plutarco teria escrito um livro hoje perdido; já Aulo Gélio a ela se refere como uma vetus quaestio. Sobre essa questão, ver Striker, 20Io. Esta comentadora menciona a ataraxía como um possível elemento distintivo do pirronismo por comparação à Nova Academia. (p. 195) Porém, segundo Sexto (HP I, 232), o acadêmico Arcesilau teria dito que o fim da filosofia seja a suspensão do juízo (epokhê), que se faz acompanhar da tranquilidade da alma (ataraxía).

7 A filosofia de Arcesilau, diz Sexto, parece-lhe "[...] ter algo em comum com o que os pirrônicos dizem; mesmo, sua persuasão e a nossa é virtualmente a mesma...” (HP I, 232)
} 
Diversos estudos recentes examinaram a ataraxía sextiana ${ }^{8}$. Muito frequentemente, em vista mesmo do fato de Sexto a apresentá-la como um fim, ela foi abordada de modo análogo àquele com que parece se fazer presente na filosofia de Pirro. O cético buscaria a suspensão do juízo por causa de seu poder de conduzir o cético a atingir sua meta, a imperturbabilidade. E, nessa linha interpretativa, com frequência a ausência de crenças tem sido vista como uma espécie de estado mental ou um distanciamento de si que seria diretamente capaz, segundo Sexto, de produzir a tranquilidade que os céticos buscam como seu fim último ${ }^{9}$. M. Burnyeat disse, por exemplo: : "Para citar Epiteto, tente somente crer ou descrer, de fato, que o número de estrelas é par. Eu repito: tente. Torne-se vividamente consciente de sua incapacidade de pensar de ambos os modos. Assim é como o cético quer que você se sinta sobre tudo, incluindo sobre se o que eu estou dizendo é verdadeiro ou falso [...]. Isso é a ataraxía." (Burnyeat, 1984, p. 132). Segue-se daí que uma leitura correta do ceticismo sextiano deveria fazer com que a prática investigação se subordine ao fim de obter a ataraxía, se possível for. Mas seria mesmo possível praticar uma investigação da verdade no seu sentido pleno se esta mira de saída a mera renovação da suspensão do juízo, de onde se haure a ataraxía?

Burnyeat entende que a "ataraxía é, entre outras coisas, uma questão de não se preocupar mais com a verdade ou a falsidade"(Burnyeat, I984, p. I2I), o que, se for o caso, parece ter implicaçóes para esse tema. Annas e Barnes, por sua vez, observam: "parece haver algo particularmente não-cético em admitir que as investigaçóes céticas terão o resultado que o cético mais desejava antes de iniciá-las [a ataraxía]." (Annas \& Barnes, I985, p. I7I). O cético antigo teria assim, segundo eles, subsumido sua investigação a uma concepçáo de felicidade que talvez seja pouco atraente ou mesmo incompreensível para nós. Podemos, todavia, dissociar a investigaçáo cética da busca pela ataraxía e considerá-la, simplesmente, como uma investigação sobre os limites do nosso conhecimento, como teria proposto Sócrates: “...Se acreditarmos que as atividades intelectuais são boas em si mesmas, nós não sentiremos como algo perverso ou trivial prosseguir com nossas investigaçóes filosóficas a despeito do seu efeito no nosso bem estar..." (Ibid.)

Um diagnóstico similiar está implícito na contraposição que Paul Woodruff faz entre o que denomina "pirronismo terapêutico" e "pirronismo investigativo". Woodruff entende que os chamados Modos de Enesidemo, esquemas argumentativos

\footnotetext{
8 Dentre outros que trataram do tema, ver Annas and Barnes, 1985, Machuca, 2006, McPherran, I989, Smith, 2000, Striker, 1990, Svavarson, 20II. Nem todos estes comentadores endossam essa leitura tradicional. Smith, em particular, distancia-se a ela, como veremos adiante.

9 Para uma exposição dessa interpretação tradicional, ver Smith, 2000, p. I7-2I.
} 
que partem da constatação de conflitos perceptivos considerados segundo diversos casos (as diferenças entre os animais, os homens, os sentidos etc.) com o propósito de engendrar a suspensão do juízo, tal como apresentados por Sexto Empírico, podem ser objeto de uma dupla interpretação: eles podem ser vistos, ou bem como estratégias demonstrativas, ou bem apenas como estratégias retóricas. Analogamente, podemos entender que o conflito apresentado por cada um desses Modos, ou bem nos compeliria por uma necessidade demonstrativa, decorrente da força dos argumentos compreendidos como refutaçóes, ou bem por uma necessidade psicológica. Woodruff relaciona a primeira leitura ao ceticismo socrático - este sim "verdadeiramente zetético e aporético" (Woodruff, 20IO, p. 213) - mas julga que a tendência predominante no pirronismo de Sexto é a "terapêutica": o interesse de Sexto seria o de realizar, através da suspensão do juízo, uma higiene mental, valendose dos modos como ferramentas para induzir ao relaxamento da mente. (Ibid, p. 2IO-2II). Em contraste com os céticos investigativos, "os céticos terapêuticos [...] uma vez que encontraram uma oposiçáo equilibrada entre dois pensamentos ou percepçôes, não buscam ir mais longe. Investigar é uma parte muito pequena de sua prática..." (Ibid, p. 2I2).

A versão do ceticismo antigo que encontramos na obra de Sexto Empírico é, de longe, a mais bem elaborada de que dispomos. Ela claramente resulta, em boa medida, de uma reelaboração de materiais provenientes de fontes mais antigas, que Sexto parece se esforçar em conciliar em busca de produzir um arcabouço filosófico coerente. Náo devemos descartar a hipótese de que talvez aqui Sexto estivesse diante de duas perspectivas herdadas do ceticismo anterior que resistissem a uma convivência plenamente harmônica. Mas procuraremos aqui sustentar -- exclusivamente com base nos conceitos sextianos, considerados no sentido próprio que eles parecem adquirir no seu contexto -- que a zétesis, em seu sentido epistêmico, como efetiva preocupação filosófica com a obtenção da verdade, e a ataraxía, tal como ele a compreendeu, poderiam se conciliar mais satisfatoriamente; que a ataraxía, nessa medida, pode ser compreendida sem que se deva abrir mão da efetiva intenção que esses céticos tiveram de se apresentar como "os que investigam". Para tanto, procuraremos mostrar, primeiramente, que a noção de ataraxía, particularmente nas $\mathrm{Hi}$ potiposes, adquire um sentido particular, talvez diverso daquele que encontramos no pirronismo mais antigo; ela se converte eminentemente numa imperturbabilidade de ordem intelectual, isto é, relativa a uma espécie mais restrita de perturbaçáo, ela mesma de natureza intelectual (o que não significa, como veremos, que ela não se articule com outros sentidos desse conceito). Em seguida, vamos examinar, com o intuito de corroborar essa leitura, o papel desempenhado nessa discussão, pela "metáfora de Apeles" que, além de ilustrar como o cético encontra a ataraxía, nos parece 
oferecer um fio condutor para compreender o encadeamento deste conceito com outros de sua filosofia. Concebida como um resultado apenas provisório de um percurso intelectual em aberto, a ataraxía parece assim conectar-se, como pretendemos mostrar, com a própria percepção, por parte do cético, de que a investigaçáo pela qual esse filósofo pretendia originalmente conhecer a verdade antes de se converter num cético pode, efetivamente, auferir um estatuto filosófico próprio e constituir, afinal, o ceticismo.

Por fim, sustentaremos que a posse da ataraxía, embora sempre situada no terreno precário da experiência meramente pessoal do filósofo cético, não apenas não obsta, mas requer a investigação, no sentido que Sexto a concebe, para obter seu lastro filosófico próprio, no que tange ao diagnóstico implícito sobre a disponibilidade da verdade que caracteriza o ceticismo. Trata-se então de defender, em suma, que esses elementos do pirronismo sextiano, zétesis e ataraxía, possuem uma articulação coerente mais profunda do que normalmente se percebe.

Iniciaremos nosso trajeto procurando precisar o escopo da noçáo sextiana de ataraxía na sua relação com outros conceitos com os quais está mais intimamente associada, em particular com a metriopátheia (a moderação das afecções).

\section{Ataraxía e metriopátheia}

Como vimos no início do texto, a finalidade do ceticismo é enunciada de forma dúplice: ela envolve ausência de perturbação com relação aos assuntos de opinião (dóxan ataraxían) e moderação nas afecções que náo se pode evitar. Mas em que medida podemos, como Annas e Barnes sugerem, articular esses conceitos no interior de uma concepção determinada de "felicidade"?

Em Contra os Éticos Sexto de fato vincula explicitamente ataraxía à noçáo de eudaimonía. Indagando se a existência de algo bom ou mal por natureza (tese assumida pelos filósofos dogmáticos, contra a qual ele argumentara) poderia conduzir a uma vida feliz, Sexto escreve: "Os céticos [...] nem afirmando nem negando algo gratuitamente, mas tudo examinando, ensinam que, para os que supóem que há bom e mau por natureza haverá uma vida infeliz, enquanto que, para os que nada determinam e suspendem o juízo, 'a vida é a mais cômoda'" ${ }^{10}$ (AM, XI, III). Crer na existência de algo que é bom ou mau por natureza, argumenta Sexto, tornará aquele que crê inevitavelmente prisioneiro de sua crença, quer ele obtenha ou náo aquilo que busca. Por outro lado, quando se evidencia que nada se pode esta-

\footnotetext{
${ }^{10}$ Sextus Empiricus, 2000, Adversus Mathematicos (doravante AM).
} 
belecer pela razão como bom ou mau por natureza, segue-se a "libertação da perturbação e uma vida tranquila" (Ibid., p. I30). Diz Sexto que "[...] esse ensinamento [de que o bom e o mau decorrem apenas do juízo humano] é certamente peculiar ao ceticismo; portanto, é próprio do ceticismo assegurar uma vida feliz (tò eudáimona bion)... É feliz a pessoa que se conduz sem perturbação e, como diz Timão, em um estado de paz e calma." (Ibid., p. I40, Cf. Ibid., p. I30).

A relação entre a ataraxía e a felicidade, nessa obra, parece ademais dependente da admissão de que toda perturbação deriva da intensidade (syntonos) das experiências. "Toda a infelicidade decorre de uma perturbaçáo [...] e toda perturbação decorre de intensamente buscar certas coisas ou de intensamente evitar certas coisas." (Ibid., II2). A busca da metriopátheia, por sua vez, é proposta segundo um modelo similar, havendo, ao que parece, uma diferença da ataraxía quanto às causas de perturbação: no caso da ataraxía, ela deriva das opiniôes sobre o que é bom ou mal; no caso da metriopátheia, de afecçôes se impóem necessariamente e, não podendo ser suprimidas pela suspensão, podem ser ao menos moderadas (Ibid., I42). Segundo Sexto, o cético, com relação às coisas sobre as quais se pode opinar serem boas ou más, no que tange à escolha ou recusa dessas coisas, "permanece imperturbado" e é "perfeitamente feliz". Mas o "necessário" — isto é, as afecçóes que resultam de uma experiência sensível involuntária e náo-racional — náo se pode remover pelo método cético, pois não se pretenderá persuadir que não se experiencia aquilo que se impóe com necessidade. Mas, mesmo neste caso, o ceticismo é de alguma utilidade, alega Sexto com base em consideraçóes sobre a natureza variada das causas da perturbação involuntária, sobre a não-responsabilidade daquele que sofre os males sobre sua experiência e, finalmente, sobre o modo como a crença na existência de bens e males naturais adiciona-se à experiência vivida e duplica o sofrimento: "Assim, a perturbaçáo decorrente da opiniáo sobre algo mal como sendo mal é por vezes pior do que a decorre da coisa real que se diz má" (Ibid.).

A concepção de ataraxía aqui apresentada parece próxima da que se atribui a Pirro, ao menos no sentido em que a ataraxía corresponderia a uma vivência filosófica derivada a uma espécie de distanciamento quando se experiencia o bem e o mal, graças a uma supressão das crenças sobre o que é bom ou mau por natureza. Ao mesmo tempo, essa discussão indica algumas diferenças importantes. Enquanto Pirro teria proposto a indiferença (adiaphoría) diante das afecçóes ou a ausência de afecçôes (apátheia), Sexto, mais modestamente, diz, como vimos, que "o cético não é inteiramente livre das perturbações (aokléton), pois ele é molestado pelas afecçôes necessárias, como o frio, a sede e outros sentimentos desse tipo" (HP I, 29-30, Cf. DL, IX, p. 66 ss.). Em nenhum momento, ademais, Sexto sugere que o ceticismo deva conduzir a uma espécie de errância, nem que o cético devesse abandonar sua 
vida ativa. Nas Hipotiposes, Sexto, que era médico, sublinha as afinidades entre o ceticismo e a escola metódica, uma dissidência da escola empírica da medicina grega (HP I, 236-240). Parte dessas afinidades estão relacionadas com o fato de que o cético admite um critério para a ação, a saber, o phainómenon, pelo qual segue a vida comum segundo o que ele julga serem seus quatro aspectos: o ensinamento da natureza, a força do páthos, a tradição dos costumes e leis e - sobretudo importante neste caso -- a instrução das tékhnai, pela qual o cético não é inativo naquelas que adota (um aspecto da adesão à "vida comum" particularmente enfatizado no pirronismo sextiano [HP I, 23-24]) $)^{11}$.

Já as Hipotiposes parecem oferecer um panorama diverso, ao menos em parte, sobre a ataraxía. Comparando as discussôes análogas sobre a moral em ambas as obras, Bett vê indícios de que as Hipotiposes sejam posteriores, retomando e aprimorando discussóes de Contra os Éticos ${ }^{12}$. Dentre as diferenças reconhecíveis entre ambas, haveria não apenas uma diferença no modo de recusar as crenças dogmáticas acerca do bem e do mal, ${ }^{13}$ mas um tratamento diverso da relaçáo entre a ataraxía e a eudaimonía. Diversamente do que vimos ocorrer em Contra os Éticos, nas Hipotiposes estas nunca são identificadas. Sexto nunca afirma, nas Hipotiposes, que o ceticismo é produtor dessa condição e sobre a noção de eudaímonia nada se afirma positivamente; ela é mencionada apenas no contexto da crítica às concepçôes estóicas de bom, mau e indiferente, como algo que os dogmáticos alegam obter embora fracassem nisso (Sextus Empiricus, 2000, p. I45). Igualmente, as alusóes ao potencial das concepçóes dogmáticas sobre a moral em produzirem perturbação são comparativamente mais sucintas (HP I, 215; HP III, 237-8; HP III, 273-5).

De todo modo, nas Hipotiposes, como vimos, a ataraxía é indicada como o fim do pirronismo e, no capítulo dedicado ao fim do ceticismo, ressurgem alusóes similares às de Contra os Éticos sobre os efeitos benéficos da suspensão relativamente às crenças sobre o bem e o mal - tanto em associação à ataraxía quanto à metriopátheia. Porém, importa destacar a presença aqui de outro aspecto da ataraxía que, ao menos nessa obra, parece ganhar uma dimensão mais fundamental; um aspecto do qual parece não haver traços nas porçôes conhecidas do Contra os Dogmáticos, da qual faz parte Contra os Éticos -- em que pese o fato de não dispormos das porções

\footnotetext{
${ }^{11}$ Sobre esse tema, ver Frede, I987, e Porchat, 2006.

12 A esse respeito, ver a introdução de Richard Bett em Sextus Empiricus, 2000, p. xxiv-xxviii.

13 Segundo Bett (ibid.), Sexto adotaria, em Contra os Éticos, uma espécie de dogmatismo negativo, ao sustentar que o cético nega que exista bem, mal ou indiferente por natureza, enquanto nas Hipotiposes ele suspende o juízo sobre o que as coisas realmente seriam a esse respeito, como faz corriqueiramente. Esse argumento é criticado por Svavarsson, 20II, que sustenta que algumas das alegaçóes de Sexto nessa direçáo devem ser compreendidas como meramente dialéticas.
} 
dessas obras que seriam correspondentes ao primeiro livro das Hipotiposes, onde Sexto oferece os esclarecimentos a que aqui nos referimos. Aqui, a ataraxía surge em contraposição a um tipo igualmente fundamental de perturbação, que é aquela que motivou originalmente o cético à sua investigação filosófica: "Pois os céticos começaram a filosofar com o propósito de decidir acerca dos fenômenos e apreender qual é verdadeiro e qual é falso, para assim obter a tranquilidade; mas eles se depararam com uma disputa equipolente e, incapazes de decidi-la eles suspenderam o juízo. E quando eles suspenderam o juízo, a tranquilidade nos assuntos de opinião se seguiu fortuitamente..." (HP I, 25).

Se perturbação existe aí, ela diz respeito ao desconhecimento do que é verdadeiro ou falso, de modo que caberia falar igualmente de uma perturbaçáo intelectual e de uma ataraxía analogamente intelectual (por oposição a uma dimensão mais propriamente moral dessa tranquilidade, relacionada com a suspensão sobre as crenças sobre o bem e o mal, bem como a metriopátheia $)^{14}$. A suspensão de crenças sobre o bem e o mal é, também nas Hipotiposes, parte do escopo da ataraxía. Mas, na sua dimensão intelectual, a ataraxía relacionar-se-ia com um conjunto mais amplo de crenças e, a bem dizer, com uma perturbação mais específica.

Insistamos um momento neste ponto. Em outra passagem, Sexto informa que originalmente os futuros céticos estavam "[...] perturbados pela anomalia das coisas (pragmasin anomalian), em dúvida sobre a qual das alternativas deviam assentir" (HP I, I2). Segundo Diógenes Laércio, Enesidemo teria também dito que as coisas se relacionam gerando "anomalia e perturbação" (DL, IX, 78). Mas o que seria essa anomalia? Talvez uma ilustração se ofereça nos diferentes Modos que esse filósofo propôs, e Sexto retomou em sua investigação, para indicar como o cético obtém a suspensão: os objetos são percebidos de modos conflitantes segundo os sentidos que os percebem, as circunstâncias de percepção, os elementos que interferem na percepção etc. Ora, não é evidente que uma anomalia dessa espécie seja por si mesma uma causa de perturbação (no mesmo sentido em que o excesso de calor ou uma crença exacerbada de que o dinheiro seja um bem, seja "bom por natureza", poderiam ser). Mesmo que alguns dos casos considerados por Enesidemo possam estar

\footnotetext{
${ }^{14}$ Para estabelecer essa distinção seguimos aqui Smith, 2000, que sugere uma divisão entre três categorias de fins buscados pelo pirrônico sextiano. A tranquilidade "intelectual", produzida pela contradição entre as filosofias; a tranquilidade "moral", decorrente da crença filosófica na crença de algo ser bom ou mau por natureza; e a metriopátheia, a moderação das afecçóes inevitáveis. (v. p. 28-30, 37-39). Svavarsson, 20II, p. 25-27, por sua vez, opõe uma ataraxía "epistêmica" (derivada da simples suspensão de crença independentemente do conteúdo) à ataraxía sobre os conteúdos da moral (sobre as crenças sobre se há bem ou mal por natureza), embora não as veja como duas espécies de ataraxía. Ele entende que apesar de Sexto aludir a uma ataraxía "epistêmica" ela é inteiramente derivada de seus argumentos sobre a moral (p. 19, 29).
} 
relacionados a problemas de ordem prática (ou possam ter implicitamente consequências práticas), este não é, em geral, o gênero de problemas aí contemplados. Quando se indaga se o remo na água é torto (imerso na água) ou reto (quando retirado da água), trata-se de querer saber qual das faces contraditórias e conflitantes com que determinada coisa se mostra pode ser tomada como propriamente pertencente a ela (se alguma o é). Antes, parece-me tratar-se aqui do tipo de perplexidade específica que o discurso filosófico grego pretende apontar diante da experiência como ocorre no famoso aforismo de Heráclito em que no mesmo rio entramos ou não entramos, ou diante da constataçáo parmenidiana de que os seres que se oferecem na experiência comum náo podem verdadeiramente ser. No caso do pirronismo, parece-me, é a própria diversidade insuperável dessas diversas reaçóes filosóficas às anomalias que adentra ela mesma esse campo.

Deverei seguir Heráclito (segundo quem predicados opostos são igualmente inerentes ao ser real das coisas) ou Parmênides (segundo quem o ser não se revela em nenhum deles)? E talvez nesse aspecto haja lugar para algum esclarecimento sobre a enigmática expressão "megalophysêis tón anthrópon" - que circunscreve o conjunto dos "homens de talento" ou de nobre estatuto como o daqueles que ocorreu de se perturbaram e que, por isso, puseram-se a investigar. Trata-se talvez daqueles que seriam suscetíveis, não só de uma capacidade investigativa especial, mas da curiosidade -- de perturbaçáo diante desses eventos -- que os motiva a buscar a verdade diante de casos como esse. Em suma, a perturbação que move inicialmente o ceticismo parece constituir uma perturbaçáo definida, de ordem especulativa, situada no plano da reflexão filosófica. Analogamente, o sentido básico dessa ataraxía buscada pelo cético seria circunscrito, não apenas ao âmbito das opinióes, mas a um domínio específico de opinióes, de natureza filosófica (sejam elas adotadas por filósofos profissionais ou por pessoas comuns, na medida em que essas opinióes forem objeto de interesse em um contexto filosófico ${ }^{15}$. Nesse sentido, talvez devêssemos falar também de uma ataraxía "relativa" - no sentido em que dela só são propriamente beneficiários os que seriam de saída suscetíveis à perturbação que ela dissolve.

Essa caracterização talvez permita, por sua vez, a diferenciar com maior nitidez (mesmo que Sexto não se ocupe disso em seu texto) dois modelos diversos pelos quais a ataraxía é pensada por esse filósofo: um modelo intelectual, situado em um nível filosófico, e um modelo moral (que, a rigor, seria mais aparentado ao da metriopátheia, uma vez que sua superação está associada, num caso ou no outro, a um

\footnotetext{
${ }^{15}$ Não cabe aqui, como se poderia talvez supor, suspeitar de "insulamento" filosófico (isto é, do recorte de temas como se fossem exclusivos da reflexáo filosófica sem efeitos na vida prática). Apenas tratam-se de temas que pela sua natureza são eminentemente, ainda que não exclusivamente, tratados pelas investigaçóes filosóficas ou "científicas".
} 
modo específico de experienciar o bem e o mal) ${ }^{16}$. Isso não significa que esses modelos não se articulem; ao contrário, como vamos indicar, parece-me que esse aspecto intelectual (mesmo se eventualmente introduzido posteriormente) pode ganhar uma função estruturante, por assim dizer, no interior do ceticismo pirrônico de Sexto, conferindo à ataraxía no sentido moral (tema este que, embora mais antigo, tem um tratamento relativamente limitado nas Hipotiposes) seu sentido próprio em um todo coerente. A ataraxía proveniente da suspensão sobre se há um bem ou mal por natureza seria mais facilmente assimilável, independentemente da adoção de uma posição cética, mas ela surgiria aqui como uma espécie de benefício indireto da outra ataraxía mais específica. Por ora, essa distinção nos oferece uma primeira razáo para suspeitar que a tese de que a epokhé produz uma espécie de "relaxamento mental" (um relaxamento como um fim em si mesmo diretamente decorrente da suspensão de crenças) está longe de explicar o significado da ataraxía sextiana.

Para observar melhor esse ponto, contudo, detenhamo-nos um instante na famosa metáfora de Apeles, que Sexto emprega para ilustrar como o cético descobre a ataraxía.

\section{A metáfora de Apeles}

... Dizem que (Apeles) estava pintando um cavalo e queria representar na pintura a espuma na boca do cavalo; mas ele foi tão malsucedido que desistiu, arremessando a esponja na qual limpava a tinta dos pincéis a pintura. E a esponja, quando atingiu a pintura, produziu a representação da espuma. Ora, os céticos buscavam obter a quietude decidindo acerca das anomalias no que aparece [aos sentidos] e naquilo que é pensado; sendo incapazes de fazê-lo, eles suspenderam o juízo. Mas quando suspenderam o juízo, a liberdade da perturbação seguiu-se como que casualmente, tal como a sombra segue o corpo... (HP I, 28-29)

Nenhum cético anterior que conheçamos, salvo engano, empregou essa metáfora pictórica para se referir à descoberta da ataraxía perante a suspensão (diversamente do que ocorre com a metáfora da sombra, mencionada por Diógenes Laércio, DL, $\mathrm{XI}$, IO7) ${ }^{17}$. Mas ela pode bem ser uma herança do pirronismo mais antigo, posto que Apeles de Cós foi um célebre pintor naturalista grego, retratista oficial de Alexandre, que também o teria acompanhado em sua expedição pela Ásia. A tradição

\footnotetext{
${ }^{16}$ Smith, 200o, também se refere a dois modelos distintos da ataraxía, de um lado enfatizando a natureza perturbadora da intensidade e de outro a perturbaçáo referente ao conflito das opinióes (que, em nosso entender, é apenas um prolongamento da perturbação intelectual original). Por outro lado, ele considera como um conjunto único as discussóes das Hipotiposes e de Contra os Éticos.

${ }^{17}$ Sobre esta frase divergem Machuca, 2006, p. I16, para quem ela não subentende que haveria uma relação necessária entre essas duas coisas e Svavarsson, 20II, p. 26, para quem isso ocorre.
} 
associou o ceticismo ao ilusionismo pictórico: segundo testemunho reportado por Eusébio de Cesaréia, Pirro teria sido pintor antes de se dedicar à filosofia, e Anaxarco teria comparado a realidade à pintura ${ }^{18}$. Seja como for, isso não significa que a metáfora não possa ter adquirido um sentido próprio no ceticismo de Sexto, onde ela está visivelmente conectada com o que denominamos ser o aspecto intelectual da ataraxía. Como ela relata a própria descoberta da ataraxía, esta seria uma razáo, aliás, para supor que esse sentido intelectual particular da ataraxía entâo descoberta tenha alguma primazia relativamente aos demais. Mas, além disso, essa metáfora parece conectar a descoberta da ataraxía a outros aspectos importantes da narrativa do percurso intelectual pelo qual o cético adota sua filosofia.

Antes de avançar, não será demais enfatizar a importância que a narrativa desse percurso intelectual possui no ceticismo sextiano. Em aparente conformidade com o modo como apresenta o ceticismo como um gênero de filosofia próprio (em contraste com dogmáticos e acadêmicos), Sexto não define o ceticismo pela posse de "dogmas", nem mesmo de algum dogma específico que o caracterizaria. Embora entenda que o ceticismo pode receber denominaçóes diversas, ele o define, como vimos, como uma capacidade de produzir antíteses (dynamis antitetiké). A essa capacidade se associa uma visão filosófica própria, uma "persuasão" que permite ao cético conciliar essa sua prática investigativa e suspensiva com uma visão de mundo (Cf. HP I, I6). Decerto, ela não se pode se configurar pela postulação de nenhuma verdade, e por isso mesmo Sexto informa, logo na introdução das Hipotiposes, que sobre nenhum dos temas tratados os céticos afirmam que as coisas sejam positivamente como eles dizem ser, mas que apenas reportam como as coisas lhe aparecem naquele momento, ao modo de um cronista (HP I, 4). Ora, uma parte fundamental da narrativa daquilo que ao cético aparece como filosoficamente importante é precisamente a narrativa do percurso percurso intelectual que o conduziu, desde sua busca inicial pela verdade, a essa perspectiva investigativa em que ele agora se situa e que constitui o seu ceticismo. A rigor, esse percurso é parte integrante de sua visão filosófica das coisas.

Como vimos, essa narrativa se oferece não apenas no texto em que Sexto apresenta o fim do ceticismo, mas igualmente nesta outra descrição de como ele se originou: "Homens de talento, perturbados pelas anomalias das coisas, sem saber ao que deveriam dar assentimento, buscaram na filosofia um meio de determinar o que é verdadeiro ou falso para assim obter a tranquilidade da alma.” (HP I, I2, 26).

${ }^{18}$ Segundo Sexto, Anaxarco de Abdera, discípulo de Demócrito que teria igualmente composto a comitiva filosófica que viajou ao oriente com Alexandre, "[...] comparou as coisas existentes a uma cena de pintura e supunha que elas se assemelhavam às impressóes vividas durante o sono ou a loucura." (Sexto AM VII, 88) 
Analogamente ao modo como Apeles buscou finalizar sua pintura, os "homens de talento" buscavam, intranquilos, a verdade, para superar sua perturbação. Nesse momento inicial, prévio à descoberta da ataraxía e à adoção do ceticismo, tais homens consideraram as explicaçôes filosóficas disponíveis e depararam com uma "disputa equipolente" -- pela qual nenhuma pôde se revelar mais aceitável que as demais, dada a vulnerabilidade de cada uma delas às objeçóes que lhes podiam ser dirigidas (Ibid.). Em vez de reconhecimento da verdade, adveio entáo um estado reiterado de suspensão do juízo (Cf. HP I, Io), a que passivamente esses investigadores foram conduzidos diante das diversas alternativas filosóficas. Tanto para Apeles como para os céticos, trata-se inicialmente de enfrentar um insucesso provisório em obter uma representação adequada, filosófica ou artística, do real.

Ambos, porém, como diz a metáfora, atingem seu objetivo. E a metáfora precisamente pretende salientar como isso ocorre: de uma maneira fortuita e inesperada. Mas o que isso significa, exatamente? $O$ fato mesmo de o cético se valer aqui de uma metáfora poderia sugerir que estivéssemos diante de um evento que transcende a possibilidade de uma explicação mais precisa, mas isso não é uma razão para não a interrogarmos sobre o seu sentido. Talvez ela ilustre o simples fato de que a não há uma relação necessária entre a investigação e a descoberta da ataraxía, que uma coisa não é demostrada a partir de outra; mas, mesmo que seja esse o caso, a metáfora parece aqui mais enigmática do que esclarecedora. Afinal, se o cético diz que permanece buscando a verdade e a suspensão é inicialmente vista como algo que precisamente corrobora sua frustraçáo diante dessa meta, como se poderia compreender essa total reversão de perspectiva?

Pode ser tentador interpretar a metáfora como uma alusão indireta a uma desistência da investigação, posto que Apeles lança a esponja no quadro como que desistindo de obter o resultado esperado ${ }^{19}$. Mais uma vez, essa leitura demasiado literal não se concilia com o conjunto de informaçôes disponíveis: se o cético alega que permanece investigando, a metáfora alega que o cético descobre sua tranquilidade de modo surpreendente a despeito de permanecer na mesma investigação. Assim, isso parece indicar outro aspecto em que a literalidade da metáfora pode ser enganosa. Tanto o cético quanto Apeles alcançam o que buscavam, mas o fizeram por meios diversos daqueles pelos quais esperavam alcançar. Em ambos os casos esse sucesso ocorre casualmente. Mas, no caso de Apeles, a obtenção do seu resultado finaliza plenamente sua busca (da qual, aliás, ele já parecia ter desistido). No caso

\footnotetext{
${ }^{19}$ Annas \& Barnes, 1985, p. I68, por exemplo, entenderam a metáfora de Apeles sugerindo que, "[...] analogamente, o investigador [cético] abandona sua busca de conhecimento, joga fora sua esponja acadêmica e supreendemente encontra a tranquilidade..."
} 
do cético, porém, há um enlace mais complexo das finalidades em jogo. Para alcançar a ataraxía, ele buscava a verdade, mas a permanece buscando. Não se pode, nesse sentido, dizer que a busca tenha sido perfeitamente concluída. Mas ele igualmente buscava a verdade porque, por esse meio, encontraria a ataraxia (que suprimiria a perturbação específica derivada de ele não poder decidir qual aparência das coisas seria a correta); ele a encontrou, porém, sem ter encontrado a verdade e, mais ainda, através da reiteração indefinida da busca da verdade.

A metáfora, nesse sentido, não se limita a indicar a casualidade de um evento; ela parece conter uma mensagem um tanto paradoxal sobre o significado dessa descoberta. Em certo sentido, tudo se passa como se uma mesma situação (a investigação, realizada num estado de ignorância da verdade) antes objeto de perturbação e da frustração, pudesse agora, por uma mudança de ponto de vista, e sem que nada mais se transformasse, mostrar-se como ocasião de ataraxía. E mais, a transformação ocorrida precisa ser entendida em um sentido tal que a ataraxía passa a ser reconhecida naquilo mesmo que era parte integrante (ou ao menos extensão) da experiência original de perturbação. Dizer apenas que essa descoberta é inesperada ou gratuita não explica como seria possível compreender alguma coerência dessa transformação, se é que isso é possível. Mas seria possível avançar no esclarecimento do que poderia, ao menos em princípio, corresponder uma ataraxía compreendida nesses termos?

Como dissemos, a descoberta da ataraxía decorre, em alguma medida, do significado que o percurso investigativo confere à experiência intelectual da impossibilidade de reconhecer a verdade. Há de pesar aí aquilo que Porchat sugeriu ser uma "decantação da experiência" subjetiva de um repetido fracasso nas reiteradas tentativas de obter a verdade, que gradativamente introduzem uma outra visão geral do panorama da busca filosófica ${ }^{20}$. Outros comentadores salientaram a importância que parece adquirir a confiança que o filósofo cético passa a desenvolver na sua capacidade de reiterar as oposiçóes e de reconhecer a precariedade da razão ${ }^{21}$. Sem

\footnotetext{
${ }^{20}$ A expressão é de Porchat. Formulando sua reconstrução pessoal do pirronismo sextiano, ele escreve: "Essa experiência repetida da suspensão necessária do juízo, essa impossibilidade sempre renovada de qualquer decisão, fazem-nos perder pouco a pouco o anseio antigo por uma verdade fugidia. E nos ocorrerá talvez, se a experiência se renova suficientes vezes, deparar, como consequência por assim dizer casual da mesma epokhé, aquela tranquilidade que outrora buscávamos na posse impossível da verdade. Isto porque não mais ansiamos pelo que não mais parece caber buscar. É importante também realçar que essa nossa postura cética de agora não se deve a nenhuma decisão filosófica. Nada estabelecemos nem demonstramos, nossa investigaçáo filosófica não tem nenhum saldo positivo a oferecer..." (2006, p. II9)

${ }^{21}$ Smith, 200o, p. 25 , por sua vez, recusa a ideia de que a tranquilidade cética corresponda a um estado subjetivo efêmero, diretamente produzido por uma suspensão de juízo particular, sustentando que ela se constitui como resultado de um processo cumulativo, dependente do aprendizado da capacidade argumentativa por parte do filósofo pirrônico. Igualmente Svavarsson (20II, p. 25) menciona que a simples suspensão do juízo não é suficiente para produzir a tranquilidade, mas que Sexto poderia ter sugerido (embora não o faça) que a tranquilidade depende da capacidade do cético em suspender o juízo.
} 
dúvida esses elementos desempenham papel importante. Além disso, a descoberta da ataraxía deve estar associada a uma perda da expectativa de que a verdade venha a ser finalmente obtida através da investigação; embora certamente o cético não possa se antecipar nessa conclusão, ele pode ao menos admitir como plausível que esse estado tende a se perpetuar.

Embora tudo isso caiba no âmbito das conjecturas, parece-me que a descoberta da ataraxía envolveria ainda dois outros passos. Um deles seria a descoberta, pelo cético, de que sua perturbaçáo inicial era causada por uma crença prematura na capacidade racional de dissolver as anomalias apresentadas pelas coisas. Graças a isso, o cético poderia ter relativizado uma crença inicial sua - que nunca é explicitada, mas que se pode facilmente presumir como tendo sido implicitamente admitida por ele: a crença de que descobrir a verdade seria um bem em si mesmo e que sua perturbação inicial era em boa medida produto dessa crença, e de um desejo imoderado de obter a verdade. Uma vez que a experiência filosófica permitiu arrefecer essa crença e a imoderaçáo que ela trouxe consigo (mas não o simples desejo de obter a verdade), tornar-se-ia possível prosseguir na investigação segundo uma perspectiva mais moderada ${ }^{22}$. E a supressão da perturbação inicial nesse sentido -- do excesso de perturbação derivada de uma crença dogmática acerca do bem e do mal -- acaba assim por se converter num meio de obtençáo da ataraxía. Isso não significa, é claro, que essa ataraxía tenha sido obtida como produto da presença de uma concepção mais básica, proveniente do modelo "moral" a que nos referimos; ao contrário, nossa sugestáo é a de que a descoberta da ataraxía nesse sentido intelectual pode ser vista como contendo implicitamente um modelo próprio a ser indutivamente aplicável no caso de outras crenças acerca do bem e do mal, onde a imoderaçáo possa se mostrar igualmente danosa. Esta segunda descoberta poderia ser vista como um corolário da primeira.

Outro ponto importante que parece estar em jogo na descoberta da ataraxía é o reconhecimento, por parte do cético, de que sua postura intelectual pode rivalizar, em alguma medida, com as demais filosofias, na medida em que estas pretendem se arrogar um benefício moral. Talvez esse seja um elemento decisivo para compreender como, para além das críticas pontuais às teorias propostas pelos dogmáticos que o cético teria oferecido durante a fase pré-cética de sua investigação, o cético acabou por reconhecer que essa atividade investigativa, inicialmente indeterminada, pôde finalmente almejar um estatuto filosófico próprio -- pode se tornar, afinal, o "ceti-

\footnotetext{
${ }^{22}$ Diversamente, Sedley, 1983, p. Io, entende que o que caracteriza o ceticismo helenístico, de modo geral, é o abandono do desejo pelo conhecimento.
} 
cismo". Ao invés de configurar, como certamente teria parecido ao investigador perturbado, um estado intelectual precário, cujo sentido se esgota em sua auto superação (na forma da adesão a um dogmatismo que se mostrasse digno de aceitação), o rigor intelectual da permanência na investigaçáo acabou assim por se assenhorar de sua identidade filosófica própria.

Este último ponto mostra-se especialmente importante ao levarmos em conta um outro aspecto da casualidade da descoberta da ataraxía. Poder-se-ia pensar que Sexto estivesse se referindo, por meio dessa metáfora, a uma espécie de iluminaçáo, a uma descoberta eventual que poderia advir a algum filósofo particular e não a outro. Mas não é disso que se trata. Ele não apenas se exprime de um ponto de vista geral, em nome dos "céticos", mas um ponto de vista que é aquele do filósofo que foi capaz de reconhecer a ataraxía em um sentido tal que a converteu no fim do seu ceticismo. E nesse sentido, parece-me que a descoberta da ataraxía, mesmo sendo um evento casual, como os demais que se alinham nesse percurso intelectual, no sentido preciso em que o é, não pode ser dele suprimida sem desfigurar o ceticismo sextiano. Trata-se de algo como uma clef de vôute pela qual essa filosofia, segundo Sexto, ganha o sentido preciso que possui como filosofia, distinguindo-se de uma investigação da verdade ainda inconclusa que poderia ser em tudo similar ao ceticismo pirrônico, especialmente do ponto de vista epistêmico, mas náo por isso constituir uma filosofia. Que descoberta seria essa se não aquela pela qual o filósofo se apercebe de que o rigor próprio de sua posição investigativa é suficiente para determinar uma posição filosófica própria, que se acompanha de uma crítica ao modo como o dogmatismo não apenas são é incapaz de alcançar os fins que prometem (epistêmicos e morais) mas apenas agrava aqueles que se apresentam naturalmente ao longo desse percurso? ${ }^{23}$

É bem verdade que, em outra obra, Contra os Homens de Saber, Sexto se refere ao percurso cético sem a ele acrescentar a ataraxía como um fim: "(Os céticos) experimentaram, com relação aos saberes (mathematon) mais ou menos o mesmo que o fizeram com relação à totalidade da filosofia. Pois eles abordaram esta última com o desejo de obter a verdade, mas suspenderam o juízo quando confrontados com o conflito equipolente e a anomalia das coisas, e o mesmo ocorreu com os saberes que eles

\footnotetext{
${ }^{23}$ Machuca, 2006, discutindo a questão de saber se a busca por ataraxía pode ser considerada natural, escreve "[...] Contrariamente a essa visão, eu acredito que o cético considera que a escolha da ataraxía como seu objetivo apoia-se em circunstâncias fortuitas, tais como seu ambiente social, cultural e filosófico e desse modo sua busca não é intrínseca ao ceticismo" (p. I25). Não julgamos haver elementos suficientes para decidir esse debate, mas esta afirmação não nos parece conforme ao papel filosófico que a ataraxía adquire (ainda que de modo sempre revisável) no ceticismo pirrônico de Sexto.
} 
buscaram adquirir, buscando também aí encontrar a verdade, mas encontraram similares aporias que não ocultaram..." (Sextus Empíricus, 2002, i, 6). Por que seria o tema da ataraxía aqui omitido? Duas possibilidades de interpretação podem ser conjecturadas. Primeiramente, esse texto se apresenta explicitamente como uma reflexão análoga e posterior àquela que os céticos fizeram no que tange aos assuntos de filosofia. Talvez a ataraxía seja aqui omitida simplesmente por tratar-se de um tema impertinente no que tange à discussão dos saberes sobre os quais versa essa obra (gramática, retórica, geometria, aritmética, astrologia e música). Talvez ela possa estar simplesmente pressuposta como algo já obtido através da reflexão filosófica.

Por outro lado, não se deve excluir que esse texto apenas reflita uma concepção provisória diversa acerca de como organizar de modo mais coerente os elementos componentes do percurso cético. Náo percamos de vista, afinal, que a descoberta da ataraxía como consequência da suspensão do juízo náo deixa de ser reconhecida por Sexto, mesmo nas Hipotiposes, como intrinsecamente provisória: “...Até agora dizemos que o objetivo do cético é a tranquilidade nos assuntos de opiniáo e a moderação das afecções inevitáveis" (HP I, 25) ${ }^{24}$. Esta passagem, em particular, corrobora a ideia de que a associação entre suspensão e ataraxía ganha seu sentido como parte de um percurso investigativo no qual a verdade permanece no horizonte. Seja como for, as Hipotiposes refletem o modo como Sexto parece ter julgado, àquela altura, mais adequado e coerente organizar tais temas.

Essas consideraçóes exigem que mencionemos ainda um outro aspecto dessa narrativa sextiana. Não estamos oferecendo esta conjectura como algo que correspondesse a uma descrição precisa da ordem histórica dos eventos, tal como se deram na experiência real de Sexto ou de outro cético. Isso não poderia ser avaliado e, a rigor, os fatos conhecidos não a parecem corroborar. $\mathrm{O}$ que nos parece estar em jogo, como dissemos, é sobretudo a compreensáo de como se puderam reorganizar de modo coerente, segundo Sexto, os materiais provenientes da tradição cética, em contraste com outras possibilidades disponíveis ${ }^{25}$. A centralidade da dimensão intelectual da ataraxía, neste sentido proposto, apenas espelharia a primazia da noção da investigação cética numa reconstrução coerente dos elementos constitutivos do ceticismo pirrônico por parte de Sexto.

\footnotetext{
${ }^{24}$ Grifo nosso.

${ }^{25}$ Segundo o acadêmico Arcesilau, o fim seria a suspensão do juízo. (V. HP I, 233) Para Enesidemo, por sua vez, o fim seria o prazer. (Eusébio de Cesareia, Praeparatio Evangelica, XIV, 8, 4)
} 


\section{Ataraxía e terapia cética}

Assumimos acima que a coerência da postura filosófica cética depende de admitir que, para o cético, permanece sendo necessário buscar a verdade. Mas por que isso seria necessário? O cético estava, antes de mais, perturbado pelo modo como os fenômenos se mostravam de modo enigmático, e a investigação cética, por ora, não foi capaz de suprimir tais enigmas, a despeito de produzir a ataraxía: sua visão parcial da situação lhe mostra que a verdade não parece estar no horizonte e que parte de sua perturbação era causada por sua sede extrema de ultrapassar essa situação investigativa. Não bastaria suspender a investigação para haurir a mesma ataraxía?

No que tange aos temas morais, talvez possamos cogitar que a investigação se faria necessária sobretudo por causa do poder atrativo que o discurso filosófico sobre o bem e o mal (ou mesmo nossas crenças espontâneas a esse respeito) pode exercer diante das situaçóes concretas com que o filosofo vier a se deparar. Talvez seja algo dessa natureza que Sexto tivesse em vista quando associa diretamente a permanência na investigação e a ataraxía cética na passagem abaixo. Explicando o lema cético de que "a todo discurso racional se opóe um outro discurso racional de igual peso", Sexto assinala que alguns céticos o compreendem como uma exortaçáo, significando "a todo o discurso se deve obter um discurso racional de igual força... Eles fazem essa exortação aos céticos -- prossegue Sexto -- para preveni-los de serem seduzidos pelos dogmáticos a abandonarem sua investigação e, assim, através da precipitação, perderem o que lhes aparece como ausência de perturbaçáo, a qual, como eu sugeri acima, eles estimam que sobrevém à suspensão do juízo sobre tudo.” (HP, I, 205). Esta passagem, por sua vez, não se refere à suspensão do juízo sobre os temas morais, e sim à "suspensão do juízo sobre tudo".

Que razóes poderiam suscitar a necessidade da investigação como um meio de auferir a ataraxía pensada segundo o modelo intelectual acima considerado? A citação anterior poderia sugerir, mais uma vez, que suprimir a perturbaçáo seria uma motivação suficiente para permanecer investigando, e não o oposto. Um dos problemas dessa interpretação, porém, parece-me dizer respeito, na falta de um melhor termo, ao lastro filosófico próprio da posição admitida pelo cético. Mais exatamente, não se trata apenas de obter a tranquilidade num sentido individual e subjetivo, independentemente das razóes que a produzam; trata-se de uma tranquilidade articulada a um posicionamento filosófico particular, acerca da disponibilidade (ou não) de uma verdade disponível no universo das filosofias dadas.

Para examinar melhor esse ponto, é preciso considerar os termos em que Sexto - que, como sabemos, era médico, e concebe sua filosofia como estreitamente afinada à escola "metódica" da medicina - alude ao ceticismo como uma espécie de "terapia”. Como vimos na última passagem citada, o conceito chave pelo qual o 
abandono da investigação é associado à perda da ataraxía é o da "precipitação" (propéteia) — com que, nesse caso, o cético poderia vir a abandonar sua filosofia um conceito cético recorrentemente mencionado por Sexto para caracterizar a filosofia dogmática. No final das Hipotiposes, ele descreve o cético como um amigo da humanidade, um philántropos que pretende curar pelo discurso o mal do dogmático, o orgulho (oiesis), resultante da maneira precipitada com que os dogmáticos se abraçam a suas pretensas verdades. A terapia consiste, pelo que explica Sexto, em oferecer argumentos capazes de sustentar o oposto, que seriam produzidos com força proporcional ao grau com que eles são acometidos de seu mal. Basicamente, os argumentos destrutivos do ceticismo serviriam para mostrar ao dogmático que ele se apoia em razôes infundadas e, desse modo, minar sua arrogância (HP III, 28o-28I). Note-se bem que a precipitação é, portanto, resultante de uma má avaliação epistêmica, de um descuido ou incapacidade em considerar devidamente a precariedade dos fundamentos das crenças admitidas, que invariavelmente se fariam presentes nas decisóes dogmáticas. Assim, investigar, para o cético, não é outra coisa do que permanecer examinando criticamente as crenças dogmáticas e seguir exibindo sua precipitação.

A exortação sextiana à permanência na investigação pode ser lida de dois modos, ao menos. Sexto poderia apenas estar alertando ao cético que, ao descuidar da investigação, ele pode inadvertidamente dar adesão a algum dogma e, por esta razão, ser tragado pelas perturbaçôes inerentes ao dogmatismo. Investigar aqui é sobretudo um meio de neutralizar possíveis causas de perturbação, tendo em vista que o ceticismo foi portador de uma solução estável, digamos assim, para a posse da ataraxía. Mas se o sentido dessa tarefa é ele mesmo circunscrito pela adesão prévia ao ceticismo, podemos indagar por que, exatamente, a investigação não se torna dispensável. Afinal, se o cético pode, para permanecer tranquilo, simplesmente recusar-se a aderir a quaisquer dogmas, talvez bastasse suspender a investigação e contentar-se com a crença de que a verdade não será encontrada para fruir a ataraxía.

Por outro lado, parece-me possível considerar que essa exortação seja também um modo de pôr em questão, mais profundamente, a pretensão de coerência do diagnóstico cético. Pois, se o cético acusa o dogmático de não ter avaliado bem as evidências disponíveis em que baseia suas teorias, naturalmente o dogmático pode igualmente, de sua parte, acusar o cético de se precipitar em suspender o juízo quanto à existência de uma teoria filosófica que seja efetivamente capaz de oferecer uma interpretação verdadeira acerca das anomalias que inicialmente perturbavam os céticos. Seria a ataraxía cética indiferente a essa possibilidade? Salvo engano, a resposta depende de saber, em última instância, quão séria e rigorosa pretende ser a avaliação desse filósofo acerca dessa possibilidade real, em particular, e, mais geral- 
mente, do diagnóstico que provisoriamente assume acerca da pesquisa filosófica humana da verdade. Em suma, depende da seriedade com que o ceticismo se assume como uma investigação. Pois a execução rigorosa da investigação é o único meio pelo qual o cético pode almejar dispor de um bom ajuste entre a sua avaliaçáo pessoal de que a verdade não estaria disponível com aquilo que as filosofias existentes efetivamente oferecem. $\mathrm{O}$ cético pode, decerto, sempre presumir que as avaliou adequadamente (em vista de como elas se desenvolveram até aqui), bem como esperar que o resultado obtido até entáo tende a se reiterar indefinidamente. Mas, assim como não pode simplesmente pressupor que isso ocorrerá, também não pode dar as costas aos argumentos dogmáticos e decidir a priori que estarão sempre equivocados. Assim, o cético que efetivamente investiga está não apenas realizando uma terapia do dogmatismo alheio, mas corroborando sua própria ataraxía - admitida provisoriamente, como vimos -- na medida em que se certifica de que ela não está baseada em uma avaliação parcial e precipitada das candidaturas dogmáticas suscetíveis de produzirem uma solução diversa do problema ${ }^{26}$.

É fato que Sexto menciona argumentos usados pelo cético que parecem apontar noutra direçáo. Explicando como o cético opóe coisas presentes a coisas passadas ou futuras, ele sugere que, quando alguém propóe ao cético argumentos que ele pode refutar, o cético pode responder que, assim como esses argumentos não eram conhecidos antes do fundador dessa escola, os argumentos que poderão ser usados em sentido oposto talvez existam mas não os conheçamos, de modo que não devemos assentir ao que é agora visto com um argumento poderoso (Cf. HP I, 33-34). Naturalmente pode-se temer que Sexto esteja aqui produzindo uma espécie de blindagem do ceticismo, tornando-o refratário a qualquer refutação possível, oferecendo uma garantia a priori de uma certeza da posiçáo cética que parece pouco compatível com a permanência na investigação. Mas, ainda que isso não seja rigorosamente incompatível com a ideia de permanecer na investigaçáo, náo acarreta isso ao menos um esvaziamento do seu sentido, talvez revelando uma intenção de manter a ataraxía em detrimento de uma verdadeira busca da verdade?

Talvez não se possa evitar que essa estratégia argumentativa seja usada desse modo. Mas, por isso mesmo, a distinção entre uma efetiva permanência na investigaçáo da verdade e de um expediente destinado a reiterá-la artificialmente pode ser aqui bastante sutil. Mas isso pode nos dar uma pista de como compreender diversamente essa ressalva sextiana, indicando a importância de considerar o intuito com

\footnotetext{
${ }^{26}$ Para uma leitura diversa sobre as consequências da dimensão epistêmica da terapia cética para a própria manutenção da posição cética (em detrimento da discussão em sua dimensão filantrópica), ver Machuca, 2006, itens III e IV.
} 
que ela é empregada. Se essa estratégia fosse generalizada, o cético, ao que parece, prescindiria de qualquer argumento adicional. Mas isso não corresponde ao que observamos no texto de Sexto Empírico (que, salvo engano, nunca usa esse argumento independentemente, contra alguma das filosofias examinadas). De todo modo, se a ataraxía está diretamente associada à suspensão do juízo, toda nova filosofia, na medida em que pode ser detentora da verdade por razóes até então desconsideradas ou desconhecidas, deve irromper como uma fonte de perturbaçáo potencial, cuja neutralização envolve a continuidade da investigação. Nesse sentido, se o filósofo está efetivamente preocupado em partir de uma avaliação correta do poder cognitivo das filosofias disponíveis, ele também estaria implicitamente comprometido, sob pena de incoerência, a usar esse argumento de um modo limitado e circunstanciado. Desse ponto de vista, o argumento em questáo talvez possa ser entendido de outro modo: como um mero expediente provisório contra um abandono precipitado da investigação, em face do que a experiência investigativa cética, lastreada no exame do conjunto das filosofias disponíveis e nos múltiplos argumentos destrutivos que essa tradição filosófica compilou.

Essa nos parece uma razão adicional para recusar a leitura "terapêutica" do ceticismo (no sentido em que a descrevemos acima, em oposição a uma leitura "epistêmica"). Assim como os "homens de talento" que buscavam inicialmente a verdade não viam a suspensão como um fator de tranquilidade (pois a sua perturbação era motivada por uma razão de ordem epistemológica, por uma exigência referente ao que pode ser tomado como verdadeiro) náo parece razoável supor que o cético "confirmado" e mais experimentado deveria abdicar do mesmo rigor investigativo. Em vez disso, parece-me que Casey Perin (20I0, p. II5) tem razão quando diz que "a explicação que Sexto dá para a motivação do cético em busca da tranquilidade só é coerente se o cético tem um interesse na descoberta da verdade por si só e não meramente como meio de obter a tranquilidade..." Mais do que isso, parece-me que a coerência com que o cético pode haurir a ataraxía de um diagnóstico intrinsecamente provisório e subjetivo das filosofias disponíveis depende essencialmente da sua capacidade de equacionar a sua própria avaliação subjetiva dessas filosofias com a evidência efetivamente oferecida por elas.

\section{Ataraxía e epokhé}

Diante de uma hipotética acusação dogmática, de que o cético se precipitou na sua adesão ao seu ceticismo? Como vimos, não pode se não investir no rigor da sua investigação, o meio de que ele dispóe de fazer com que seu diagnóstico do estado dos saberes não se confunda com uma recusa teimosa ou preguiçosa da filosofia, 
mas reflita a situação efetiva daquilo que as alternativas filosóficas dogmáticas oferecem. Eis por que a investigaçáo deve ser portadora de um papel fundamental na sua fruição de ataraxía. Por outro lado, a experiência investigativa cética é sempre resultante de um número indefinido e necessariamente limitado de experiências da epokhé. Seria isso realmente suficiente para oferecer um panorama adequado do poder demonstrativo da razáo, diante do que o universo da filosofia efetivamente oferece? Quantas e quais experiências seriam suficientes para conduzir o cético à ataraxía? Estas questóes nos convidam a considerar, de outro ponto de vista, o problema de saber como a experiência intrinsecamente provisória e subjetiva do cético pode ganhar um valor propriamente filosófico.

Mais especificamente, como se articulam as noções de suspensão do juízo e ataraxía no interior do ceticismo pirrônico sextiano? Embora Sexto por vezes se refira às suspensôes de juízo individuais como algo que pode ser reconhecido como bom (quando alude à posição de Arcesilau), ele não apresenta a obtenção da ataraxía pelo filósofo pirrônico como o produto de uma série reiterada de suspensóes do juízo. Em vez disso, ele se exprime referindo-se, ao que parece, a uma única suspensão do juízo como a causa da ataraxía: "[...] Os céticos buscavam obter a quietude decidindo acerca das anomalias naquilo que aparece e naquilo que é pensado; e sendo incapazes de fazê-lo, eles suspenderam o juízo. Mas quando suspenderam o juizo, a quietude se seguiu como que casualmente, tal como a sombra segue o corpo...” (HP I, 28-29) ${ }^{27}$. Ademais, citamos acima um texto que Sexto se refere à ataraxía como decorrente de uma "suspensão do juízo sobre tudo." (HP I,205). Como entender esses textos? Mais de uma possibilidade se oferece.

Talvez esse sentido mais geral da suspensão do juízo pudesse ser visto como expressão de uma hipótese de que ela se repetirá, inferida a partir de um número limitado de observaçôes. Mas uma explicação mais precisa, parece-me, deveria envolver a um aspecto da investigação sextiana nem sempre devidamente sublinhado, a saber, o seu caráter sistemático ${ }^{28}$. Nos livros II e III das Hipotiposes (como nos livros correspondentes de Contra os Dogmáticos), ele pretende percorrer exaustivamente as posiçôes filosóficas de todas as áreas, bem como, nos livros Contra os Homens de Saber, o conjunto completo das "artes liberais" onde o dogmatismo lhe parece detectável. Sexto diz que os argumentos gerais oferecidos contra o critério lhe pareceriam suficientes para mostrar o infundado das filosofias dogmáticas, mas, apesar

\footnotetext{
${ }^{27}$ Grifo nosso.

${ }^{28}$ Depois de redigir esta passagem descobri que Plínio Smith pretende igualmente salientar esse ponto em um texto ainda inédito.
} 
disso, ele prossegue em um exame dos três tipos de critério propostos pelos dogmáticos. Sua justificativa é a necessidade de proceder a uma exposição que seja ao mesmo tempo "metódica e completa" (emméthodos... kai téleios, HP II, 2I). E, numa passagem que ecoará na Primeira Meditação de Descartes, Sexto diz que não se pode pretender considerar todas as opinióes, uma a uma, pois a disputa é vasta e isso conduziria a uma exposição sem método.

Isso parece indicar que Sexto reconheceu em sua investigação, graças a esse expediente metódico, alguma espécie de completude. Uma completude certamente precária e provisória, posto que a investigação deve ser sempre retomada diante de cada nova ameaça dogmática relevante. Mas náo seria essa completude, afinal, uma condição pela qual o cético poderia atingir uma espécie de "suspensão do juízo" geral, um estágio que ao menos leva a investigação a outro patamar? Este pode ser um elemento importante para detectar um ponto de inflexão a partir do qual a pode se operar uma mudança na orientação da investigação. A partir daí as novas filosofias surgiriam apenas como potenciais ameaças ao estado em que esse filósofo se encontra. Doravante tratar-se-ia sobretudo de atualizar pontualmente um diagnóstico geral do estado da questáo, que acabou por ganhar certa estabilidade, ainda que provisória. Essa estabilidade deve estar, por sua vez, relacionada ao modo como o cético reconhece nessa mesma posição um estatuto filosófico próprio, bem como a sua ataraxía; ele permitiria, ao menos, que o diagnóstico geral sobre o estado da filosofia que o cético é conduzido a aceitar como plausível, por assim dizer, se enraíze, contribuindo (assim como a investigaçáo continuada) para corroborar seu ponto de vista e oferecer alguma garantia de que ele não se estaria apenas diante de uma crença ilusória sobre a indisponibilidade da verdade.

\section{Conclusão}

Em que consiste, então, a ataraxía visada pelo cético pirrônico sextiano? Procuramos mostrar que não apenas essa tranquilidade pode ser conciliada com a investigação cética, mas que um aspecto decisivo dela reside na sua dimensão intelectual, correspondente a uma espécie de perturbação de natureza filosófica. Entre outros elementos do qual dependeria essa ataraxía, estaria o reconhecimento de que a crença na necessidade de possuir a verdade produziria uma perturbação por si mesma, e de que a investigação filosófica antes vivida sob regime de perturbação pode almejar a um estatuto filosófico próprio. A compreensão adequada desse ponto exige reconhecer que a investigação das filosofias disponíveis e a capacidade de proceder a uma epokhé generalizada a partir do seu exame é uma condição sine qua non para fruir da ataraxía. $\mathrm{O}$ cético não está buscando a ataraxía, nem a suspensão, como um fim em 
si mesmo, cujo valor é independente desse contexto apresentado e pode ser apreendido separadamente da dimensão investigativa do ceticismo, que permanece do início ao fim sendo o fio condutor principal de sua posição filosófica. $\mathrm{O}$ ceticismo que Sexto oferece corresponde aos resultados com que o filósofo se depara graças a uma preocupaçáo original que permanece viva, e é a pedra angular de todo esse percurso, a busca da verdade.

Finalmente, a busca da tranquilidade estava associada inicialmente à pretensão da superação da perturbação causada pelas anomalias através da posse da verdade, mas ela acabou advindo da impossibilidade de obtê-la por esse meio. Naturalmente, isso significa que as anomalias permanecem presentes e o cético atento à possibilidade de explicá-las, mesmo que não mais lhe pareçam perturbadoras no mesmo sentido. Elas continuam se oferecendo como parte de sua experiência de mundo, ainda que ele não se veja mais como alguém capaz de dissolver seu enigma. Caberia talvez dizer que o que mudou foi que, através de sua experiência filosófica, o cético aprendeu, de algum modo, a conviver com elas.

\section{Bibliografia}

Annas, J. e Barnes, J. (1985). The Modes of Scepticism: Ancient Texts andModern Interpretations. Cambridge: Cambridge University Press.

Bett, R. (200o). Pyrrho, His Antecedents and His Legacy. Oxford, Oxford University Press. Bolzani Filho, R. (2013). Acadêmicos versus Pirrônicos. São Paulo: Alameda Editorial. Burnyeat, M. F. (1984). “The Sceptic in His Place and Time”, in: Schneewind, J. B.; Skinner Q.; Rorty, R. (ed.) Philosophy in History. Cambridge (et. al), Cambridge University Press.

Diógenes Laércio (2013). Vida dos Filósofos Ilustres, IX ("Vida de Pirro"), in Gazzinelli, Gabriela, A vida cética de Pirro, Sáo Paulo: Ediçóes Loyola.

Eva, L. (2005). "O primeiro cético (acerca da coerência do pirronismo)”, in: SilvaFilho, W J (ed.), O ceticismo e a possibilidade da filosofia. Ijuí: Editora da Unijuí, p. 45-86.

Flintoff, E. (1980). "Pyrrho and India", in: Phronesis, vol. 25, no. I, p. 88-Io8.

Frede, M. (1987). "The Method of the So-Called Methodical School of Medicine", in: Essays in Ancient Philosophy. Oxford: Clarendon Press, p. 26I-278.

Gazzinelli, G. (2013). A vida cética de Pirro, São Paulo: Edições Loyola.

Machuca, D. E. (2006). The Pyrrhonist's ataraxia and philantropia. Ancient Philosophy 26, p. III-I38.

McPherran, M. (1989). "Ataraxia and eudaimonia in Ancient Skepticism: is the Skeptic really Happy?”, in: Proceedings of the Boston Area Colloquium in Ancient Philosophy 5, p. I35-I7I. 
Perin, C. (2010). The Demands of Reason. An Essay on Pyrrhonian Scepticism. Oxford University Press.

Porchat Pereira, O. (2006). Rumo ao Ceticismo. São Paulo: Editora Unesp.

Sedley, D. (1983). “The motivation of Greek Skepticism”, in Burnyeat, M. F. (ed.) The Skeptical Tradition. Berkeley: Univesity of California Press, p. 9-30.

Sextus Empiricus (1994). Outlines of Scepticism (HP), Tradução de Julia Annas and Johnathan Barnes. Cambridge: Cambridge University Press.

Sextus Empiricus (1997). Against the Ethicists. Tradução e comentário de Richard Bett. Oxford: Clarendon Press.

Sextus Empiricus (2002). Contre les Professeurs (Adversus Mathematikos I-6). Tradução de C. Dalimier, D. et J. Dellatre, B. Pérez. Paris: Éditions du Seuil.

Smith, P. J. (200o). "Sobre a Tranquilidade da Alma e a Moderação das Afecções", in: Ceticismo Filosófico. São Paulo: EPU; Curitiba: Editora da UFPR.

Striker, G. (1990). "Happiness as Tranquility”. Monist. 73, p. 97-IIO.

Striker, G. (20IO). “Academics versus Pyrrhonians, reconsidered”, in: Bett, R. (ed.), The Cambridge Companion to Ancient Scepticism, Cambridge: Cambridge University Press, p. 195-207.

Svavarsson, S. H. (20II). "Two Kinds of Tranquility: Sextus Empiricus on Ataraxia”, in Machuca D. E. (ed.) Pyrrhonism in Ancient, Modern and Contemporary Philosophy, Dodrecht, Springer, p. 19-32

Woodruff, P. (2020). “The Pyrrhonian Modes”, in: Bett, R. (ed.), The Cambridge Companion of Ancient Scepticism. Cambridge: Cambridge University Press, p. 208-23I. 